\title{
Economic Aspects of Small and Large Molecule Pharmaceutical Technologies
}

\author{
Richard P. Rozek \\ National Economic Research Associates, Inc. Washington, DC \\ *Corresponding Author: richard.p.rozek@gmail.com
}

Copyright $@ 2013$ Horizon Research Publishing All rights reserved.

\begin{abstract}
There are differences between small and large molecule pharmaceutical technologies from a scientific perspective. However, there do not appear to be measurable differences with respect to the economic characteristics of small and large molecule pharmaceutical projects. The economic characteristics underlying developing, manufacturing, and marketing products based on small and large molecule technologies appear to be similar. The growing importance of large molecule technologies in addressing unmet medical needs will create a need for additional research on identifying material economic differences that may require changes in public policies.
\end{abstract}

Keywords Biotechnology, Health Care, Pharmaceuticals, Regulation, Research and Development

\section{Introduction}

Research-based pharmaceutical companies have made substantial investments in large molecule or biologic technologies 1 through such activities as internal research and development (R\&D), acquisitions, and licensing. These investments have generated scientific and commercial successes. Based on worldwide sales in 2009, five of the top ten prescription pharmaceutical products were large molecule products. 2 With the growing importance of large molecule technologies for pharmaceutical companies, it is useful to compare and contrast the development,

1 Current and former staff members of National Economic Research Associates, Inc. (NERA) provided valuable inputs into this paper. Some of the analyses incorporated in this paper are based on research conducted for projects funded by several research-based pharmaceutical companies. The opinions are those of the author and do not necessarily reflect the views of any other person at NERA or any research-based pharmaceutical company. A referee provided valuable comments on an earlier version of the paper.

1 The U.S. Food and Drug Administration (FDA) describes a biologic or large molecule product as "a virus, therapeutic serum, toxin, antitoxin, vaccine, blood, blood component or derivative, allergenic product, or analogous product, or arsphenamine or derivative of arsphenamine (or any other trivalent organic arsenic compound), applicable to the prevention, treatment, or cure of a disease or condition of human beings." See Reg. Sec. 6a.262(h)(3)(i). [39] Thomas Morrow [47]

2 The leading large molecule products are: Remicade $\AA$, Enbrel $($, Avastin ${ }^{\circledR}$, Rituxan ${ }^{\circledR}$, and Humira ${ }^{\circledR}$. See “Top 200 Medicines by Sales” [48] manufacture, and sale of small molecule technologies and large molecule technologies from an economic perspective. Based on the economic analyses to date, there do not appear to be substantial differences between small and large molecule technologies in terms of length of development, R\&D costs, regulatory review times, and licensing behavior.

Certain key historical events occurred that substantially changed the economic characteristics of the pharmaceutical industry. For example, the 1962 Kefauver Harris Amendment to the Food, Drug, and Cosmetic Act (FDCA) requiring the FDA to determine that pharmaceutical products are safe and effective; and the 1984 Drug Price Competition and Patent Term Restoration Act (Hatch-Waxman Act), which also amended the FDCA, facilitated entry of generic versions of innovative products in exchange for restoring patent protection the innovative products lost due to regulatory delays. These laws were primarily directed at small molecule pharmaceutical technologies. The Diamond $v$. Chakrabarty decision in 19803 contributed to the incentives to invest in large molecule pharmaceutical technologies. There are now several emerging issues with respect to the regulatory standards for biosimilar or follow-on large molecule pharmaceutical products, patent reform, R\&D tax credits, guidelines for intercompany pricing of intellectual property, and recent court decisions that may cause changes in the pharmaceutical industry as dramatic as these prior developments. The specific resolution of these issues may create economic differences between the incentives to create, manufacture, and sell small and large molecule pharmaceutical products.

The purpose of this research is to review the structure of the pharmaceutical industry, compare the results of economic analyses assessing small molecule technologies and large molecule technologies, and highlight emerging issues that policymakers, investors, and companies must address. This paper is not a survey of the vast literature on the pharmaceutical industry Such a review is a project in itself.. The remainder of this paper is organized as follows:

- Section II describes the vertical structure of the pharmaceutical industry.

3 Diamond v. Chakrabarty [14] 
- Section III compares and contrasts the functions associated with developing, manufacturing, and marketing small and large molecule pharmaceutical products generally, and highlights the emerging issues for policymakers, investors, and companies.

- Section IV summarizes the conclusions based on the public data available at this time.

\section{Vertical Structure of the Pharmaceutical Industry}

The pharmaceutical industry has a complex vertical structure involving functions from discovery of new technologies by innovators to distributing the final product to the patients. Some participants in the industry may be involved in one or more functions. For example, a contract manufacturer performs only limited manufacturing functions whereas a research-based pharmaceutical company performs substantially more functions. The vertical structure encompasses the following functions and participants:

\subsection{Research and Development}

Inventors at academic institutions, government laboratories, start-up companies, and research-based pharmaceutical companies discover promising approaches to treating diseases.

Developers conduct clinical trials and obtain regulatory approvals for products emerging from the discovery phase. 4

Investors finance pharmaceutical $R \& D$ through a variety of sources including the retained earnings of established pharmaceutical companies, grants from government agencies, and venture capital.

\subsection{Regulation}

Lawmakers and regulators establish the rules that govern behavior of companies in the pharmaceutical and other industries including standards for determining whether pharmaceutical products are safe and effective and produced under good manufacturing practices. They also review applications from companies seeking approvals under the standards. 5
Regulatory environments continue to evolve over time and at different rates for small and large molecule products. 6

\subsection{Manufacturing}

Manufacturers obtain regulatory approvals for manufacturing activities, obtain raw materials, and produce active pharmaceutical ingredients and finished pharmaceutical products.

Contract manufacturers may perform some steps within a manufacturing process. They receive compensation related to the risks they bear.

\subsection{Selling}

Marketers disseminate relevant information about the therapeutic properties of products to members of the healthcare community (e.g., patients, physicians, pharmacists, and payers) and distribute finished pharmaceutical products.

Wholesalers (e.g., local, regional, national, and international) obtain products from manufacturers or marketers and resell the products to institutions such as drug stores, food stores, hospitals, or government facilities.

Retailers (e.g., chain and independent pharmacies), hospitals, and federal facilities provide pharmaceuticals directly to patients based on instructions (e.g., prescriptions) from physicians.

Third-party payers (e.g., government and private) collect premiums from tax revenues, employers, or individuals to pay for all or part of the patients' pharmaceutical expenses.

Patients use pharmaceutical products to treat their diseases either paying all the costs for a product out-of-pocket or relying on a third-party payer to absorb a share of the costs.

This vertical structure applies to small and large molecule pharmaceutical products. For example, both types of products embody intangible property created as part of the R\&D function. In both cases, this intangible property is developed into a finished, packaged product; tested in clinical trials; and evaluated by regulatory agencies. Those products that are ultimately approved by a regulatory agency are then marketed as ethical pharmaceutical products to treat approved indications. See Figure 1 created by the author.
4 Developers may engage contract research organizations (CROs) to perform some tasks on particular projects in exchange for specified fees. The developer, however, continues to bear the risks associated with the success or failure of the project.

5 Lawmakers and regulators at international, national, and local levels have an impact on the pharmaceutical industry in areas such as patents, securities, employment, taxes, product approvals, and pricing/reimbursement.
6 For a description of the evolution of regulations involving small and large molecule products, see J. Vernon, A. Bennett, and J. Golec [18] 


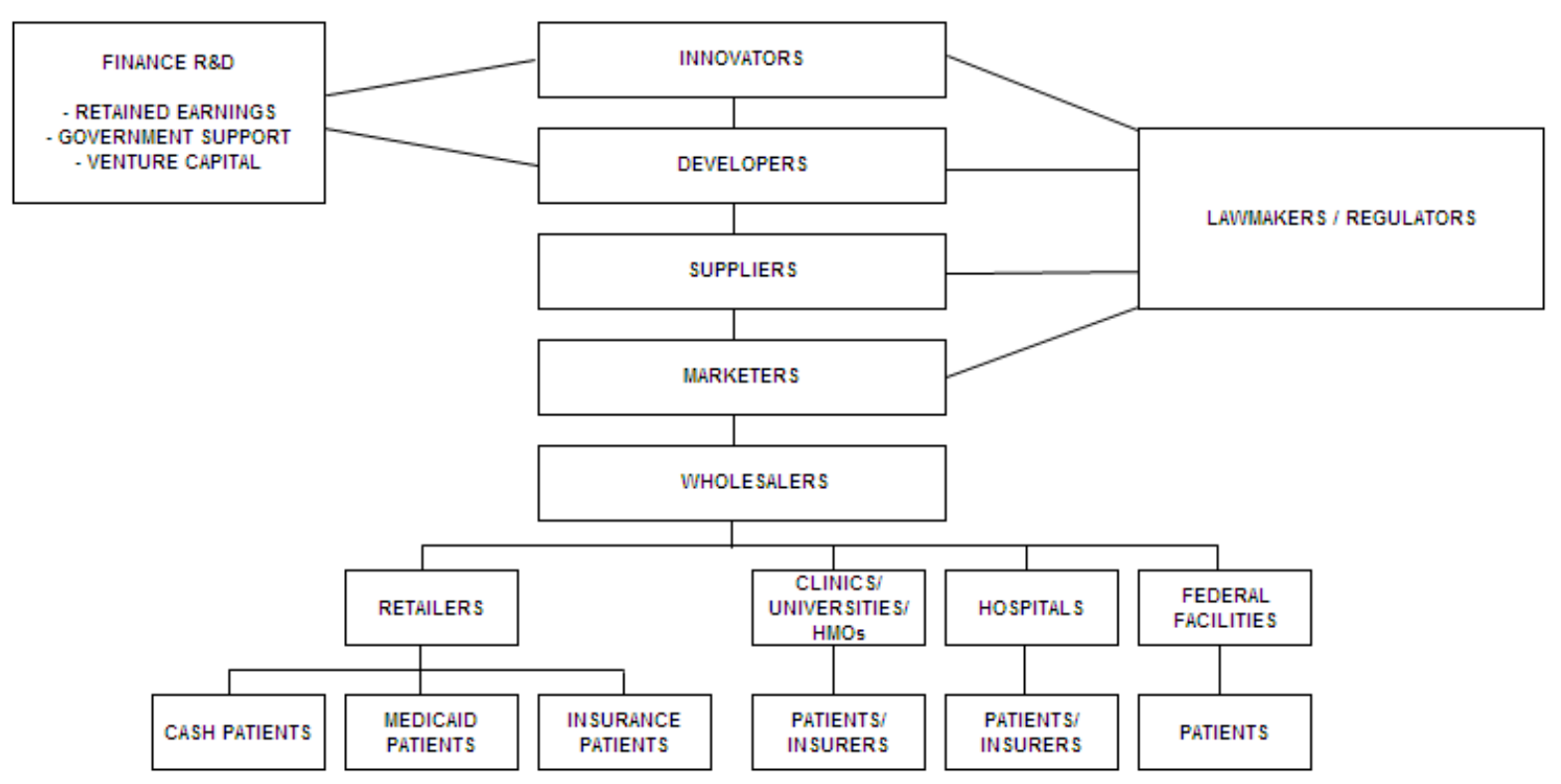

Figure 1. Vertical structure of the pharmaceutical industry

\section{Current Results and Emerging Issues on Small and Large Molecules}

The focus of this paper is on the U.S. and Europe. These regions represent substantial sales of pharmaceutical products. Research-based pharmaceutical companies are investing in large molecule technologies. $7 \mathrm{~A}$ few companies such as Amgen Inc. and Genentech, Inc. have evolved as leaders in selling large molecule products. These companies have distinguished themselves as leading biotechnology companies given their history of successfully developing large molecule products. Other research-based pharmaceutical companies have made investments in large molecule products as part of their overall R\&D portfolios. For example, Johnson \& Johnson has had a long relationship with large molecule products through its Centocor Ortho Biotech Inc. subsidiary. 8 GlaxoSmithKline plc licensed large molecule products such as

Genmab's Arzerra ${ }^{\circledR} .9$ AstraZeneca International acquired MedImmune, Inc. in 2007.10 Pfizer Inc. expanded its large molecule capabilities by acquiring Wyeth Pharmaceuticals in 2009.11 Recently, Johnson \& Johnson announced an agreement to acquire the biotechnology company Crucell NV and sanofi-aventis has made a takeover bid for Genzyme Corporation. 12 The crossover between small and large molecules by industry participants who develop, manufacture, and market ethical pharmaceutical products is

7 "Drying pharma drug pipelines and looming patent expiry of blockbuster drugs is creating an ulcer-inducing income gap expected to reach $\$ 30$ billion over the next five years. Plugging that hole with drugs from biotechs promises to be the quickest and surest way of keeping pharma going...Collaboration is the most direct path to innovation, and ultimately to the patients who need them." Carola Schropp [10]

8 Bridget Silverman [7]

9 Bridget Silverman [7]

10 Andrew Pollack [2]

11 Cynthia Challener [12]

12 Maarten van Tartwijk [27] not surprising given that research-based pharmaceutical companies seek to remain leaders in advancing the state of biomedical knowledge.

\subsection{General Trends}

There is a general trend toward a greater role for large molecule products in the pharmaceutical industry.

\subsubsection{Research and Development}

Small and large molecules must receive regulatory approval prior to being marketed as ethical pharmaceutical products. Before receiving regulatory approval, a pharmaceutical product embodying either a small or large molecule has to successfully pass several stages. Pharmaceutical companies often divide pre-approval R\&D into Basic Research, Preclinical, Phase I, Phase II, and Phase III stages. 13 During the Basic Research stage of development, pharmaceutical companies identify and test new molecules to determine their potential for treating medical problems in humans.

If the company identifies a potentially useful compound, it begins Preclinical testing. Preclinical studies involve laboratory and animal testing to evaluate whether the compound is safe for humans and to understand how the compound works against the targeted disease. Tens of thousands of compounds are evaluated in the Basic Research and Preclinical stages for safety and effectiveness. On average, only 5 out of every 5,000 compounds that enter the Preclinical stage will be tested in humans. 14 A recent study by DiMasi and Grabowski estimated the approval success rates, phase transition probabilities, length of development, out-of-pocket costs, and average capitalized costs, 15 per

13 For a description of the stages of development, see PhRMA [36]

14 PhRMA [36]

15 Average capitalized costs include the time costs associated with the 
approved ethical pharmaceutical product embodying a large molecule and compared the results to studies that focused on small molecule development projects. 16 While there are differences in specific factors between small and large molecule development projects, the overall conclusion of their work is that the total capitalized costs of developing a small molecule technology are approximately the same as developing a large molecule technology.

Pharmaceutical products that complete pre-approval R\&D must undergo regulatory review to determine whether the product is safe and effective for commercial sale. Generally, pharmaceutical companies must submit clinical data regarding the safety and efficacy of the product for human use to regulatory agencies. If a regulatory agency determines that the product meets the required standards, the product will be approved for commercial sale. The specific requirements of this process differ across countries or regions and type of molecule embodied in the pharmaceutical product being considered. 17

Despite the differing paths a large molecule product can take when being evaluated by the FDA, the total length of development in the U.S. for both a small and large molecule is on average the same; that is, they require approximately the same amount of time from initiating Phase I through approval by the FDA (90.3 months and 97.7 months for small and large molecule technologies, respectively). However, the length of each stage of development differs between small and large molecules in the U.S. A large molecule takes on average longer than a small molecule to complete Phase I and Phase II stages of development, but then takes less time to complete Phase III and the Regulatory Review process. See Figure 2 based on the literature cited above.
There has been a distinct shift in the amount of review time it takes the FDA to approve a pharmaceutical containing a large molecule. Prior to 2005, the average review time for large molecule products was greater than that for small molecule products. For products launched in 2003 (the year the CBER began sharing the approval responsibilities with CDER) the average review time was almost 37 months for large molecule products compared to 17 months for small molecule products. Since 2005, however, the review time for a large molecule product follows the same trend in terms of the average duration of review time as a small molecule, but on average takes a few months less time than a small molecule. See Figure 3. In 2011, the FDA approved 9 large molecule products with the average time to approval equal to 14.7 months. 18

The similarities and differences of the development and approval process for ethical pharmaceutical products containing either small or large molecules can be quantified and compared on average terms. The DiMasi and Grabowski biopharmaceutical study estimated the total out-of-pocket development costs per approved ethical pharmaceutical product embodying a small molecule to be 20 percent greater than the $\$ 559$ million estimated for development of a large molecule product. However, the total cost to develop a small and large molecule product when time costs (or opportunity costs) are accounted for are $\$ 1.318$ billion and $\$ 1.241$ billion for small and large molecule products, respectively. 19

\footnotetext{
development as well as the out-of-pocket (cash outlay) costs.

16 See Joseph A. DiMasi and Henry G. Grabowski [19] For earlier work on pharmaceutical development costs, see Joseph A. DiMasi, Ronald W. Hansen, and Henry G. Grabowski [20]

17 Historically, all small molecule products were evaluated for regulatory approval by the FDA's Center for Drug Evaluation and Research (CDER) and large molecule products were evaluated by the FDA's Center for Biologics Evaluation and Researcher (CBER). After June 30, 2003, the CDER began sharing the responsibility of evaluating large molecule products with the CBER. The CDER began evaluating large molecule products that fall into the following categories: monoclonal antibodies, proteins for therapeutic use, immunomodulators, and growth factors. Other types of large molecules, such as vaccines and gene therapy products, continue to be evaluated by the CBER. See "Transfer of Therapeutic Biological Products to the Center for Drug Evaluation and Research" [50]
}

18 "Biologics Approved in 2011" [3]

19 See Joseph A. DiMasi and Henry G. Grabowski [19] 
Characteristic

Approval Success Rate

Phase Transition Probability

I-II

II-III

III-Approval
Small Molecule

(1)

$21.5 \%$

$71.0 \%$

$44.2 \%$

$68.5 \%$
Large Molecule

(2)

$30.2 \%$

Length of Development

\begin{tabular}{lll} 
Phase I & 12.3 months & 19.5 months \\
Phase II & 26.0 months & 29.3 months \\
Phase III & 33.8 months & 32.9 months \\
ulatory Review & 18.2 months & 16.0 months \\
\hline Total & 90.3 months & 97.7 months \\
\hline
\end{tabular}

R\&D Costs

\begin{tabular}{ccc|} 
Preclinical & $\$ 150 \mathrm{M}$ & $\$ 198 \mathrm{M}$ \\
Clinical & $\$ 522 \mathrm{M}$ & $\$ 361 \mathrm{M}$ \\
Total Out-of-Pocket Costs & $\$ 672 \mathrm{M}$ & $\$ 559 \mathrm{M}$ \\
\hline Total Capitalized Costs & $\$ 1,318 \mathrm{M}$ & $\$ 1,241 \mathrm{M}$ \\
\hline
\end{tabular}

\section{Cost of Capital}

Discount Rate

$11.0 \%$

$11.5 \%$

Figure 2. Comparison of development characteristics for small and large molecule pharmaceutical technologies

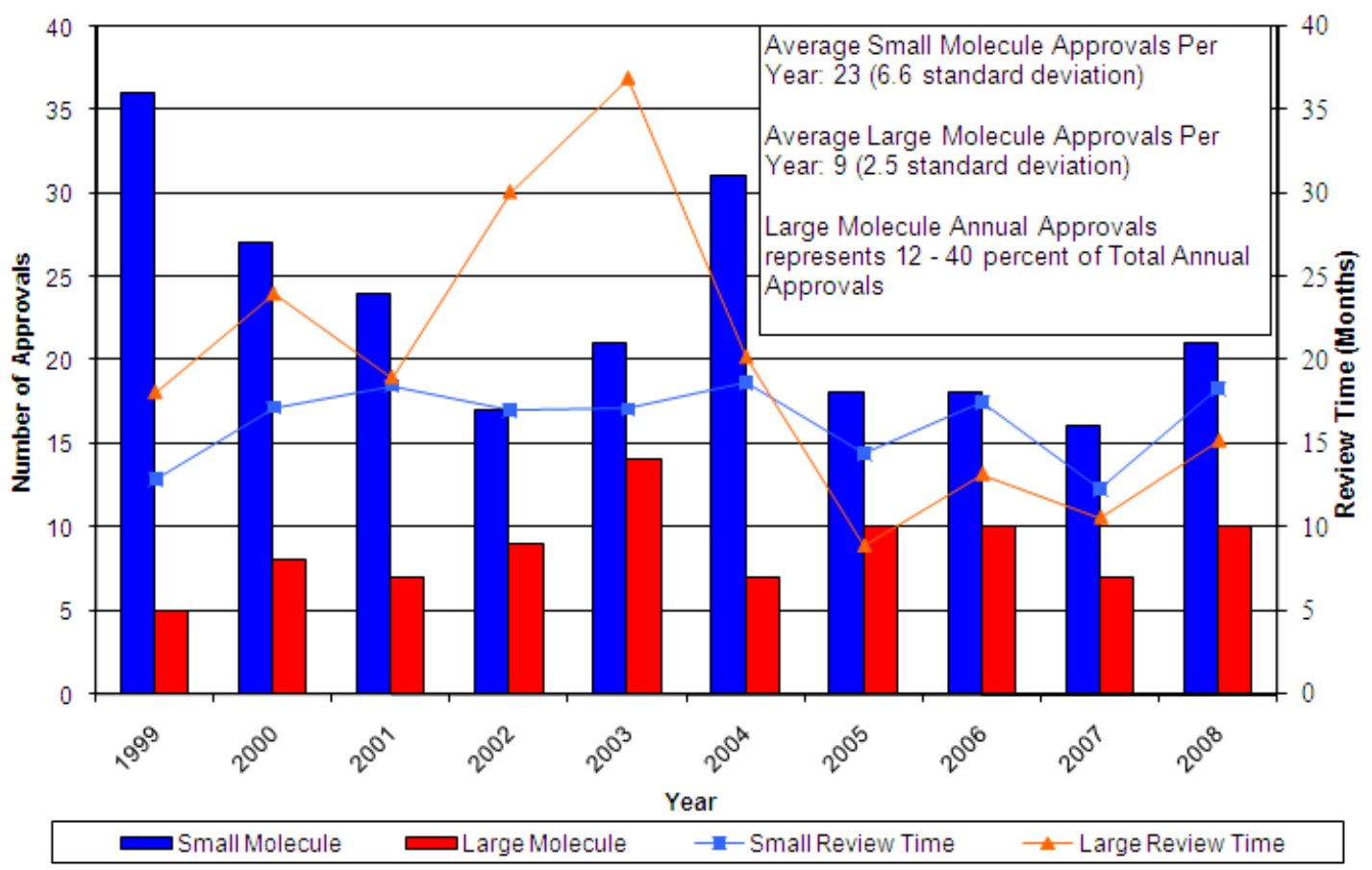

Note: Review Time represents the duration of time from filing to receiving approval by the FDA.

Source: "The Pink Sheet," F-D-C Reports, Inc., Chevy Chase, MD [collectively, TPS], 2000, Vol. 62, No. 2, pp. 5 \& 7-9; TPS, 2000, Vol. 62, No. 3, pp. 16; TPS, 2001, Vol. 63, No. 2, pp. 13-18, TPS, 2002, Vol. 64, No. 1, pp. 12 \& 14-15; TPS, 2002, Vol. 64, No. 2, pp. 13-14; TPS, 2003, Vol. 64, No, 52, pp. 5-7 \& 11-12; TPS, 2004, Vol. 65, No. 52, pp. 18-21; TPS, 2005, Vol. 66, No. 52, pp. 38-41; TPS, 2006, Vol. 68, No. 2, pp. 23-24 \& 28-30; TPS, 2007, Vol. 69, No. 3, pp. 21 \& 24-25; TPS, 2007, Vol. 69, No. 6, pp. 27 \& 29; TPS, 2008, Vol. 70, No. 2, pp. 3 \& 7-8; TPS, 2008, Vol. 70, No. 3, pp. 19-20; TPS, 2009, Vol. 71, No. 2, pp. 3, 5 \& 8-10.

Figure 3. Number of small and large molecule technologies approved by the FDA 1999-2008 


\subsubsection{Licensing}

Licensing intellectual property for small and large pharmaceutical technologies occurs regularly in the pharmaceutical industry. Licensors include government agencies such as the National Institutes of Health, universities, independent research laboratories, or established research-based pharmaceutical companies. Licensees are most often the research-based pharmaceutical companies with the experience and resources available to sponsor clinical trials, prepare regulatory dossiers, manufacture complex products consistent with regulatory requirements, and provide information to the healthcare community (e.g., patients, physicians, pharmacists, and payers). Both potential licensors and potential licensees have choices available. There are numerous innovators developing pharmaceutical technologies as well as numerous potential licensees interested in developing, manufacturing, and selling innovative pharmaceutical products for treating unmet medical needs. Even though pharmaceutical technologies differ from a scientific perspective, potential licensors and potential licensees translate the scientific characteristics of the technologies into monetary terms to facilitate evaluating alternative negotiating positions. They rely on net present value or expected net present value analyses to evaluate the benefits and costs from continuing development of the intellectual property.

Complete data are often not available in the public domain about particular license agreements. However, there are sources of public information such as attachments to filings companies make with the U.S. Securities and Exchange Commission (EDGAR Online), press releases, industry trade press such as In Vivo, published decisions in various legal proceedings, databases of licensing activity (e.g., RoyaltySource ${ }^{\circledR}$ ), and academic articles or book on licensing behavior 20 that provide useful information about licensing activities for small and large pharmaceutical technologies. Based on reviewing information on several hundred license agreements for small and large pharmaceutical technologies from such sources, there are several trends that emerge. First, license agreements for both small and large pharmaceutical technologies have been increasing over the past 20 years. Interestingly, the rate of growth for agreements involving small molecule pharmaceutical technologies has been greater than the rate of growth for agreements involving large molecule pharmaceutical technologies. Second, molecule size does not appear to be a statistically significant explanatory variable for determining the royalty rate. 21 Royalty rates are similar across technologies. The interquartile range of royalty rates for agreements involving small and large pharmaceutical technologies is 5 percent to15 percent of sales. Third, license agreements for small and large pharmaceutical technologies have forms of payments

20 See, for example, Russell L. Parr [40]

21 The agreements considered are for the core technology underlying a pharmaceutical product (e.g., composition of matter patent) rather than a patent for a research tool that would facilitate screening a large number of molecules. such as milestone payments or upfront payments in addition to royalty rates. Negotiating such payment terms is a means of sharing risks between licensors and licensees. Fourth, license agreements for small and large pharmaceutical technologies most frequently involve technologies in the preclinical stage of development. Even though a licensee might prefer a technology that is in the later stages of development (i.e., close to receiving approval for sale from a regulatory agency such as the FDA), the reality is that such well-developed technologies are not readily available in the marketplace for intellectual property. Fifth, agreements for large molecule pharmaceutical technologies are frequently in the oncology therapeutic area, whereas agreements for small molecule technologies are distributed across a broad array of therapeutic areas. A recent study found that out of 633 medicines in development that embody large molecule technologies 40.1 percent were in the oncology area. 22

\subsubsection{Manufacturing}

Manufacturing a large molecule product is generally more complicated and expensive than manufacturing a small molecule product. Since large molecule products come from a living source, the manufacturing process is more sophisticated than the chemical synthesizing process associated with manufacturing small molecule products. For example, the manufacturing process for a recombinant DNA product may involve a scientist programming instructions directly into the DNA of a cell, such as a mammalian cell or a yeast cell.23 A portion of the higher costs may be due to the fact that pharmaceutical companies have more experience manufacturing small molecule products. Costs of manufacturing large molecule products will likely fall over time as companies gain more experience with the manufacturing techniques for producing both raw materials and finished products.

\subsubsection{Selling}

Marketing small and large molecule products involves the same types of techniques that pharmaceutical companies have historically relied upon: direct contact of physicians by company representatives (detailing), medical journal advertising, direct mail to physicians, sponsoring medical symposia, sampling, 24 and direct-to-consumer advertising. Large molecule products available commercially have relatively high prices per course of therapy compared to small molecule products.

\subsubsection{Marketing}

Pharmaceutical marketers engage in some combination of the activities described above. The combinations of activities used for a given product depend on the approved indications for a product and the other properties of the product. For example, sampling may not be used for products delivered

\footnotetext{
22 PhRMA [34]

23 "The Competitive Implications of Generic Biologics" [44]

24 Since most large molecule products currently available are injections, sampling is not prevalent.
} 
through injection. Direct-to-consumer advertising helps to make people aware of a medical problem and initiate discussions with their physicians. It is most widely used for products dispensed in tablet or pill form. While sellers of some large molecule products rely on direct-to-consumer advertising (e.g., Johnson \& Johnson for Procrit ${ }^{\mathbb{B}}$ (epoetin alpha) 25, it is not generally the case. The nature of the disease (e.g., chronic or acute, seasonal or not), the characteristics of the patient population, the types of physicians (general practice or specialists) who treat patients with the disease, and the extent of competition (other treatment options and competing products) are additional factors that influence the mix of marketing activities for a given product.

\subsubsection{Prices}

Purchases of large molecule products are the most rapidly growing component of spending on pharmaceutical products in the U.S. and other countries.26 On average, a daily dose of a large molecule product costs 22 times more than a small molecule product. 27 However, "prices for biologics are more uniform across countries than prices for other drugs, and U.S. prices for biologics with identical formulations are not higher, on average, than prices for the same products in other countries." 28 Since large molecule products are not administered in a pill form that could be distributed through a retail pharmacy, most prescriptions for large molecule products are dispensed to the patient during a hospital stay or in an out-patient facility where the products are administered directly to the patient. In some countries, drugs dispensed in hospitals are not subject to price regulation. 29 Large molecule products are not subject to the same price regulation outside the U.S. as are small molecule products. Frequently, large molecule products treat disease classes with few alternative treatment options available. Lack of price regulation and limited competition are factors contributing to higher prices for large molecule products outside the U.S. 30

Given these and other factors present in the marketplace, sales for large molecule products are increasing. In 2006, sales of large molecule products increased 20 percent to total $\$ 40.3$ million compared to just over an 8 percent increase for the sales of pharmaceutical products overall.31 In 2007, the rate of growth for large molecule products was 12.5 percent, approximately twice the increase observed for pharmaceutical products overall.32 By 2014, it is expected that the sales from large molecule products will represents 23 percent of total sales of pharmaceutical products. 33

As discussed above, the number of large molecule products approved by the FDA each year remains far less

"AMA Calls for Tighter DTC Regulation" [1]

Patricia M. Danzon and Michael F. Furukawa [31]

Laurence J. Kotlikoff [25]

Patricia M. Danzon and Michael F. Furukawa [31]

Patricia M. Danzon and Michael F. Furukawa [31]

Patricia M. Danzon and Michael F. Furukawa [31]

"The Competitive Implications of Generic Biologics" [44]

Kendra Marr [23]

Bridget Silverman [7] than the number of small molecule products approved. The average number of products approved from 1999 through 2008 is 23 for small molecule products and 9 for large molecule products. During this period, large molecule products approved represented between 12 to 40 percent of the total products approved annually. Since 1996, the U.S. has had the highest ratio of large molecule products to total products approved of any developed country. 34

\subsection{Emerging Issues}

Periodically, there are developments such as the safety and efficacy standards imposed by the FDA, the Hatch-Waxman Act, and the Diamond v. Chakrabarty decision that fundamentally change the incentives facing innovators, developers, manufacturers, and marketers in the pharmaceutical industry. These developments have long-lasting effects on the revenues and costs associated with participating in the pharmaceutical industry. The healthcare marketplace is not static. Policymakers, patients, physicians, attorneys, investors, scientists, and other stakeholders are attempting to assess current events that have the potential to create major new rules for industry participants. New rules could alter the structure, conduct, and performance of the pharmaceutical industry over the next 30 years. Examples of potentially pivotal changes in the industry are: criteria for entry of biosimilar products, 35 details of patent reform, extension of R\&D tax credits, changes in transfer pricing guidelines, and impact of recent court decisions.

\subsubsection{Biosimilar Products}

The Patient Protection and Affordable Care Act (PPACA) that President Obama signed on March 23, 2010 gave the FDA authority to approve biosimilar products. The FDA must now establish the formal process it will use to evaluate and approve biosimilar products. 36

\subsubsection{Data Exclusivity}

Data exclusivity is a period of time when the imitator cannot rely on the innovator's animal testing and certain data from clinical trials to apply to a regulatory agency for approval of a similar product. The recent healthcare reform law addressed data exclusivity. It established a legal framework for biosimilar products in that the innovator receives 12 years of marketing exclusivity for large molecule products and the FDA must establish rules governing the data required for regulatory approval of a biosimilar product. 37

\subsubsection{Interchangeability}

The complex structure of large molecule products makes

34 Patricia M. Danzon and Michael F. Furukawa [31]

35 Biosimilar products are also referred to as follow-on large molecule products.

36 The PPACA includes the Biologics Price Competition and Innovation Act, which addresses the approval issues for biosimilar products. The PPACA is currently being reviewed by the U.S. Supreme Court after multiple challenges at the district court level. See Brian Dorn [6]

37 Jessica Merrill [16] 
developing an identical product difficult, if not, impossible. This issue has implications for the interchangeability of biosimilar products. The FDA's position is that biosimilar large molecule products will not be identical to the original product and cannot be easily approved. 38 The manufacturing process of large molecule products also requires a greater number of batch records, data entries, and product quality tests than small molecule products. The molecular size and complexity of large molecule products and their production in living cells means that small differences or changes in manufacturing processes may substantially change the quality, biology, and clinical activity of the products. Unlike generic versions of small molecule products, biosimilar products are not identical to their reference products even when constructed from the same genetic material using the same manufacturing techniques as the reference product. 39 Dispensing a biosimilar product may require the approval of the physician who prescribed the original product. 40 Additionally, pharmacists are generally able to substitute generic versions of small molecule products. Pharmacists do not have the same discretion to substitute biosimilars due to interchangeability and efficacy issues. 41 To allow interchangeability, a company seeking to market a biosimilar product would have to demonstrate that switching presents no additional risks to a patient. This demonstration may require that the maker of the follow-on product conduct clinical trials. 42

\subsubsection{Ever-Greening}

Ever-greening is the practice of making minor changes to a product that allows the innovator to receive additional periods of exclusivity. These changes may relate to the strength of the dosage, form of delivery, indicated use, or timing of doses via time-release mechanisms among other things. 43 Companies seeking to sell biosimilar products maintain that restrictions to prevent ever-greening are necessary to prevent the innovator from delaying entry of their products indefinitely. 44

\subsubsection{European Experience}

A pathway for the regulatory approval of biosimilar products in Europe was developed in 2004 and became effective in late 2005.45 The European Medicines Agency (EMA) has specific guidelines for establishing an approval mechanism governing the manufacture and sale of biosimilar products that are as safe and effective as the originator large

\footnotetext{
38 "Progress of biologics slow in the United States" [37]

39 Hubb Schellekens [15]

$40 \quad$ Jill Wechsler [17]

41 "Biosimilars Approval Pathways in the US and Europe- Developmen and Approval of Biosimilar mABs May Face Tough Regulatory Environment" [8]

42 Jill Wechsler [17]. Such clinical studies may cost up to $\$ 40$ million as opposed to the \$1-2 million required to demonstrate bioequivalence of generic version of a small molecule product. See John Vernon, Alan Bennett, and Joseph Golec [18]

43 Laurence J. Kotlikoff [25]

44 "Progress of biologics slow in the United States" [37]

45 Linda R. Horton [26]
}

molecule product. 46 There are three complimentary components to this process:

starting from the date of European Commission authorization, no applications for a follow-on product may be filed for eight years;

no follow-on applications may be approved for an additional two years; and an additional year of market protection is provided if the product is developed for a new indication deemed to have a substantial clinical benefit. 47

The European pathway addresses the issues discussed above. First, exclusivity is the main mechanism of protection afforded to large molecule products. The " $8+2+1$ " structure aims to allow inventors to recoup their development expenses with the recognition that patents may not suffice. Second, the issue of interchangeability is delegated to individual nations to address. The Executive Director of the EMA stated that "it is not possible we would guarantee a biosimilar is interchangeable (with its originator). Substitution is a national competency and needs to be discussed at the national level."48 Lastly, ever-greening is addressed by allowing additional indications to qualify the product for one additional year of exclusivity, but not to restart the exclusivity period.

The regulatory approval process for biosimilar products outlined by the EMA has two broad categories: general guidelines that apply to all categories of biosimilar products and specific guidelines that are dependent on the therapeutic class in question. The general guidelines include the need to show appropriate quality, purity, and comparability of in vitro and in vivo pharmacokinetic and pharmacodynamic data. 49 Due to variations in end points and surrogate markers of response that are specific to a given drug or disease (e.g., granulocyte colony-simulating factor, erythropoietin, and insulin), specific guidelines by product class were developed and differ among products. For example, randomized controlled trials of patients undergoing treatment were needed to evaluate epoetin biosimilar products, whereas preclinical data coupled with studies of healthy volunteers were adequate for the introduction of certain insulin products. 50

While the marketing authorization process is specific to each proposed biosimilar product, 51 the standard for approval is comparability. Two large molecule products are comparable if they demonstrate "highly similar quality attributes" and "no adverse impact on the safety or efficacy, including immunogenicity." 52 For a company to receive approval of a biosimilar product, it must carry out studies to show that the biosimilar "is similar to the reference medicine" and that it "does not have any meaningful differences from the reference medicine in terms of quality, safety, or efficacy." 53 The clinical studies required of an applicant

\footnotetext{
46 The Guideline on Similar Biological Medicinal Products [45]

47 Linda R. Horton [26]

48 Linda R. Horton [26]

49 Bradford R. Hirsch, and Gary H. Lyman, [5]

50 Bradford R. Hirsch, and Gary H. Lyman, [5]

51 Steven Simoens [42]

52 "The Pathway to Regulatory Approval of 'Biosimilars:' The EU" [46]

53 "Biosimilar medicines" [9]
} 
must be done in comparison to the reference product and may be costly. Relative to the reference product, the clinical development program can be shorter and less costly given that the proof of concept has already been demonstrated.54 The EMA also operates a system of fees with the fee for a biosimilar product equal to approximately 64 percent of the fee for the reference product. 55 Additionally, the EMA holds biosimilar products to the same standard as complex innovator large molecule product and requires that biosimilar products undergo the same safety and efficacy review process post approval.

\subsubsection{Patent Reform}

Periodically, proposals are made to reform U.S. patent laws that have an impact on incentives to invest in pharmaceutical technologies. In September 2011, President Obama signed into law the Leahy-Smith America Invents Act. A main provision of the new law will help reduce the backlog of patent applications at the U.S. Patent and Trademark Office (PTO) by allowing the PTO to use fees it charges to hire more patent examiners. The new law also restricts false patent marking suits and infringement suits that focus on multiple unrelated defendants, change the U.S. patent system from a first-to-invent system to a first-to-file system, and establish post patent grant review procedures. The law does not contain provisions from earlier draft patent reform legislation with respect to damages. Earlier proposed legislation contained provisions that would have allowed judges to be gatekeepers when deciding on the standards and evidence juries should have for assessing damages. Companies in the research-based industry 56 and the biotechnology industry 57 supported this gatekeeper approach to damages over the prior proposals that provided specific instructions for calculating reasonable royalty damages. The concerns with the instructions in the prior proposals were that they would result in lower penalties for infringing patents and thereby reduce the value of intellectual property. From an economic perspective, these latter proposals would have undermined the case law that encourages economically rational damage evaluations. 58

The research-based pharmaceutical industry endorsed the new law. "It reforms America's patent system and, in the process, helps promote innovation and jobs. Importantly, while the law will help spur additional innovation in the biopharmaceutical research sector, the effects will also extend to other patent-based industries." 59

\subsubsection{Capital Investment}

A long-term investment horizon has been the strategy

\footnotetext{
$54 \quad$ Patricia Van Arnum [32]

55 "Development of biosimilars" [13]

56 "We appreciate the work done by the bill's sponsors to work with all stakeholders and bring forward legislation on this important topic." See PhRMA [35]

57 "We greatly appreciate the tireless efforts of Senators Leahy, Feinstein and Specter to craft careful compromises on several key issues, including damages and post-grant review." See "Patent Bill Compromise Marks Major Step Forward toward Positive Reform" [30]

58 For specific examples, see Phillip Beutel et al [33]

59 Kate Connors [21]
}

behind the capital investment in the biotechnology industry. The industry as a whole earned its first net profit in its 40 -year history in 2008.60 However, $\$ 8$ billion of the $\$ 9.4$ billion in total profits in 2008 came from the three companies with the largest market share in the biotechnology industry: Amgen Inc., Genentech, Inc., and Gilead Sciences, Inc.61 This milestone has been offset with changes for the companies with a smaller market share given the economic downturn in the global economy in 2008. The Biotechnology Industry Association (BIO) reports that 10 biotech companies have recently declared bankruptcy.62 BIO also reports that one-third of the 360 publicly-traded biotechnology companies have less than 6 months of cash remaining to fund company operations compared to less than one-twentieth of the companies a year ago. 63 Industry experts expect consolidation among these smaller biotech companies within the next year instead of acquisitions by major pharmaceutical companies such as GlaxoSmithKline plc and Merck \& Co., Inc. 64 President Obama has proposed extending the $R \& D$ tax credits for companies that invest in $R \& D$ as a means of stimulating the U.S. economy. 65 One possibility is that the credits are extended permanently if there is tax reform as well.

\subsubsection{Transfer Pricing}

A typical research-based pharmaceutical company has operations in multiple countries. It must determine arm's length prices (transfer prices) for the transfer of intangible 66 and tangible property embodied in ethical pharmaceutical products between affiliated entities (controlled transactions). These companies must comply with country specific rules for reporting income in each country in which they operate. In the U.S., analyses of controlled transactions follow the Internal Revenue Service Final Regulations (TD 8552), Relating to Intercompany Transfer Pricing under Section 482, issued July 1, 1994 (Section 482 regulations). ${ }^{67}$ The governing principle for valuing both intangible and tangible property in the Section 482 regulations is the arm's length standard; that is, the result that would have been realized had uncontrolled entities engaged in the same transaction under the same circumstances as in the controlled transaction. ${ }^{68}$

In testimony before the U.S. House of Representatives' Committee on Ways and Means on July 22, 2010, Stephen E. Shay, Deputy Assistant Secretary for International Tax Affairs at the U.S. Department of the Treasury, stated that "[w]e conclude, based on our analysis of available data, that there is evidence of substantial income shifting through

\footnotetext{
60 "Biotech's Good News, Bad News" [4]

61 "Biotech's Good News, Bad News" [4]

Keith J. Winstein [22]

Keith J. Winstein [22]

Kim Hart [24]

Christi Parsons [11]

The phrases intangible property and intellectual property are used interchangeably in this paper.

67 Organisation for Economic Co-operation and Development's Transfer Pricing Guidelines for Multinational Enterprises and Tax Administrations are endorsed by tax authorities in developed and developing countries throughout the world.

68 Reg. Sec. 1.482-1(b)(1) [38]
} 
transfer pricing. In response the Administration's FY 2011 Budget includes proposals that would reduce incentives to transfer U.S. intangibles [intellectual property] offshore to related parties, which is one of the transfer pricing techniques used to shift income out of the United States."69 If there are changes in transfer pricing guidelines for intellectual property, research-based pharmaceutical companies may make changes in the location of various activities. For example, R\&D laboratories may be shifted to locations outside of the U.S.

\subsubsection{Court Decisions}

The Diamond v. Chakrabarty decision provided incentives to devote resources to R\&D in the biotechnology. "Since the Court's decision, the biotechnology industry in the United States has improved and saved lives around the world through breakthrough medical therapies, increased crop yields, and renewable fuels." 70 The recent district court decision in Association for Molecular Pathology et al. v. United States Patent and Trademark Office et al. may adversely impact these incentives. In March 2010, Judge Sweet ruled that certain claims of seven gene patents held by Myriad Genetics Inc. were invalid.71 In reaching a decision, Judge Sweet distinguished the current situation from the Diamond v. Chakrabarty decision based on whether the patentee modified the underlying biological material. Myriad Genetics Inc. appealed the decision to the U.S. Court of Appeals for the Federal Circuit (CAFC). In July 2011, CAFC reversed the District Court's decision on the non-patentability of Myriad's composition claims covering two breast cancer genes and a method claim for screening potential cancer therapeutics via changes in cell growth rates. It upheld the District Court's decision on the other method claims. 72 In June 2013, the U.S. Supreme Court ruled in the matter that genes cannot be patented.

Another interesting matter decided by the U.S. Supreme Court is Mayo Collaborative Services v. Prometheus Laboratories, Inc. This matter involves a test to measure a patient's metabolite level. The Court ruled unanimously that two patents covering the test are based on a law of nature and are not patentable.

Both of these cases are important for the health care generally. However, they do not involve pharmaceutical technologies directly so they are beyond the scope of this paper.73

\section{Conclusions}

Research-based companies in the pharmaceutical industry are actively engaged in expanding their $\mathrm{R} \& \mathrm{D}$, manufacturing, and marketing activities beyond small molecule technologies to large molecule technologies. To understand the

\footnotetext{
"Testimony of Stephen E. Shay" [43]

Statement of Jim Greenwood [41]

"Opinion" [29]

"Opinion" [28]

"Transcript of Oral Argument" [49]
}

implications of this trend, this paper compared and contrasted the public economic data on small and large molecule technologies for the pharmaceutical industry generally.

The economic issues such as development costs, extent of patent protection, and regulatory environment are the same for small and large pharmaceutical technologies. Based on the economic analyses to date, there do not appear to be measurable differences with respect to the economic characteristics of small and large molecule projects. Even though there are differences between small and large molecule technologies from a scientific perspective, the economic characteristics underlying developing, manufacturing, and marketing products based on small and large molecule technologies appear to be similar. The growing importance of large molecule technologies in addressing unmet medical needs will create a need for additional research on identifying material economic differences that may require changes in public policies.

There are current policy debates with regard to issues such as standards for biosimilars, extent of patent reform, renewal of R\&D tax credits, guidelines for intercompany pricing, and impact of certain court decisions. Any of these areas could result in fundamental changes to the risks and rewards for investing in R\&D in small and/or large molecule pharmaceutical technologies. Stakeholders must continue to monitor developments in these areas.

\section{REFERENCES}

[1] "AMA Calls for Tighter DTC Regulation," FiercePharma, May 9, 2009,http://www.fiercepharma.com/story/ama-calls-f or-tighter-dtc-regulation/2008-05-09

[2] Andrew Pollack, "AstraZeneca Acquires a Biotech Company," The New York Times, April 24,

2007,http://www.nytimes.com/2007/04/24/business/24drug. html

[3] "Biologics Approved in 2011," The Pink Sheet, January 9, 2012, p.8

[4] "Biotech's Good News, Bad News," BusinessWeek, March $12,2009$.

[5] Bradford R. Hirsch and Gary H. Lyman, "Biosimilars: Are They Ready for Primetime in the United States?: European Experience," Medscape Education, http://www.medscape.or g/viewarticle/747320_4

[6] Brian Dorn, "Biosimilars Law in Limbo," Law360, January 25, 2012,http://www.law360.com/articles/300764/biosimilar s-law-in-limbo

[7] Bridget Silverman, "Big Pharma's March into Biotech Could Make Big Biologics a Big '09 Theme," The Pink Sheet, March 23, 2009, p. 42-43

[8] "Biosimilars Approval Pathways in the US and EuropeDevelopment and Approval of Biosimilar mABs May Face Tough Regulatory Environment," Market Research News, 
March 31, 2011,http://www.salisonline.org/market-research/ biosimilars-approval-pathways-in-the-us-and-europe-develo pment-and-approval-of-biosimilar-mabs-may-face-tough-reg ulatory-environment/

[9] "Biosimilar medicines," European Medicines Agency, Special Topics,http://www.ema.europa.eu/ema/index.jsp?cur l=pages/special_topics/document_listing/document_listing_0 00318.jsp\&murl=menus/special_topics/special_topics.jsp\& $\mathrm{mid}=\mathrm{WC} 0 \mathrm{~b} 01 \mathrm{ac} 0580281 \mathrm{bf0}$

[10] Carola Schropp, "Partnering-The Key to Innovation," Wall Street Journal, September 17, 2010, p. B4B

[11] Christi Parsons, "Obama to Seek Extension of R\&D Tax Credits," Los Angeles Times, September 5,

2010,http://www.latimes.com/news/nationworld/nation/sc-dc -tax-credits-20100905,0,7562048.story

[12] Cynthia Challener, "Follow-on Biologics Present Opportunity to Big Pharma," ICIS.com, February 10, 2010,http://www.icis.com/Articles/2010/02/15/9333235/foll ow-on-biologics-present-opportunity-to-big-pharma.html

[13] "Development of biosimilars," Generics and Biosimilars Initiative, January 7,2011,http:/gabionline.net/Biosimilars/ Research/Development-of-biosimilars

[14] Diamond v. Chakrabarty, 447 U.S. 303 (1980)

[15] Hubb Schellekens, "Biosimilar therapeutics- what do we need to consider?," Oxford Journals, NDT Plus, Volume 2, Issue supplement 1, pp. i27-i36,

http://ndtplus.oxfordjournals.org/content/2/suppl_1/i27.full

[16] Jessica Merrill, "On the Cusp of Biosimilars: Reform Ushers in Next Generic Drug Era," The Pink Sheet, March 30, 2010, pp. 3-5.

[17] Jill Wechsler, "Exclusivity vs. Patents," Washington Report, Pharmaceutical Executive, August 2007, p. 36.

[18] John Vernon, Alan Bennett, and Joseph Golec, "Exploration of Potential Economics of Follow-on Biologics and Implications for Data Exclusivity Periods for Biologics," Boston University Journal of Science \& Technology Law, Volume 16, Issue 1, Winter 2010, pp. 55-76, http://www.bu.edu/law/central/jd/organizations/journals/scit ech/volume161/documents/Vernon_WEB.pdf

[19] Joseph A. DiMasi and Henry G. Grabowski, "The Cost of Biopharmaceutical R\&D: Is Biotech Different? Managerial and Decision Economics, Volume 28, 2007, pp. 469-479

[20] Joseph A. DiMasi, Ronald W. Hansen, and Henry G. Grabowski, "The Price of Innovation: New Estimates of Drug Development Costs," Journal of Health Economics, Volume 22, No. 2, March 2003, pp. 151-185

[21] Kate Connors, "Giving Credit Where Credit is Due," PhRMA Media Release, September 20, 2011.

[22] Keith J. Winstein, "Cash Dries Up for Biotech Drug Firms," The Wall Street Journal, March 16, 2009, pp. B1- B2.

[23] Kendra Marr, "Biotech Campaigns for Easier Access to Generic Drug Market," The Washington Post, August 13, 2008, p. D-1.

[24] Kim Hart, "The Download: No Money, No buyers for Struggling Biotech Firms," The Washington Post, March 23, 2009 , p. D1.
[25] Laurence J. Kotlikoff, "Simulating Innovation in the Biologics Industry: A Balanced Approach to Marketing Exclusivity," (unpublished manuscript), September 2008, p. 3, 9.

[26] Linda R. Horton, “The European Experience with Follow-on Biologics Legislation," presentation at the Federal Trade Commission Roundtable on Follow-on Biologic Drugs, Washington, DC, November 21, 2008.

[27] Maarten van Tartwijk, "J\&J, Crucell Reach Accord on Deal," Wall Street Journal, October 10, 2010, p. B2

[28] "Opinion," Association for Molecular Pathology et al. v. United States Patent and Trademark Office et al., U.S. Court of Appeals for the Federal Circuit, 2010-1404, decided July 29, 2011.

[29] "Opinion," Association for Molecular Pathology et al. v. United States Patent and Trademark Office et al., U.S. District Court - Southern District of New York, 09 Civ. 4515, filed March 29, 2010.

[30] "Patent Bill Compromise Marks Major Step Forward toward Positive Reform," Biotechnology Industry Organization ("BIO"), April 2, 2009.

[31] Patricia M. Danzon and Michael F. Furukawa, "Market Watch, Prices and Availability of Biopharmaceuticals: An International Comparison," Health Affairs, Volume 25, No. 5, p. 1353,1361 .

[32] Patricia Van Arnum, "Opportunities in the Biosimilars Market, Analysis of the opportunities and challenges in the biosimilars market," Pharmaceutical Technology, Volume 34, Issue 3, March 2,

2010,http://pharmtech.findpharma.com/pharmtech/Ingredien ts/Opportunities-in-the-Biosimilars-Market/ArticleStandard/ Article/detail/ 660530

[33] Phillip Beutel, Alan Cox, Bryan Ray, and Marion Stewart, "A Brief Comment on the Damages Provisions in the Patent Reform Act of 2009," NERA Economic Consulting, March $12,2009$.

[34] PhRMA, "Biotechnology Research Continues to Bolster Arsenal Against Disease with 633 Medicines in Development," Medicines in Development: Biotechnology, 2008, http://www.phrma.org/sites/phrma.org/files/attachmen ts/Biotech\%202008.pdf.

[35] PhRMA, "Statement on Patent Reform Act of 2009," March 3, 2009.

[36] PhRMA, "The Drug Development and Approval Process," Medicines in Development: Biotechnology, 2008, p. 59, http://www.phrma.org/sites/phrma.org/files/attachments/Biot ech\%202008.pdf

[37] "Progress of biologics slow in the United States," Annual Rx Report, Drug Store News, August 13, 2007, p. 88, 90.

[38] Reg. Sec. 1.482-1(b)(1).

[39] Reg. Sec. 6a.262(h)(3)(i). http://www.fda.gov/RegulatoryInf ormation/Legislation/ucm149278.htm

[40] Russell L. Parr, Royalty Rates for Pharmaceuticals \& Biotechnology, Yardley, PA: Intellectual Property Research Associates, Inc., 6th Edition, 2006

[41] Statement of Jim Greenwood, President and CEO of the 
Biotechnology Industry Association, celebrating the 30th anniversary of the Supreme Court ruling in Diamond v. Chakrabarty, June 16, 2010,http://www.bio.org/news/pressre leases/newsitem.asp?id=2010_0616_03

[42] Steven Simoens, "Biosimilar medicines and cost-effectiveness," Dovepress Journal: ClinicoEconomics and Outcomes Research, February 2011, Volume 11, pp. 29-36, http://www.dovepress.com/biosimilar-medicines-andcost-effectiveness-peer-reviewed-article-CEOR

[43] "Testimony of Stephen E. Shay," Hearing on Transfer Pricing Issues, Committee on Ways and Means, U.S. House of Representatives, July 22, 2010,http://waysandmeans.house.g ov/media/pdf/111/2010Jul22_Shay_Testimony.pdf

[44] "The Competitive Implications of Generic Biologics," Remarks of Commissioner Pamela Jones Harbour, ABA Sections of Antitrust and Intellectual Property Law, Intellectual Property Antitrust: Strategic Choices, Evolving Standards, and Practical Solutions, Federal Trade Commission, San Francisco, CA, June 14, 2007, pp. 3-4

[45] The Guideline on Similar Biological Medicinal Products (CHMP/437/04), October 30, 2005,http://www.emea.europa. eu/docs/en_GB/document_library/Scientific_guideline/2009/
09/WC500003517.pdf.

[46] “The Pathway to Regulatory Approval of 'Biosimilars:' The EU," AARP International, International Affairs Issue Brief, May 1, 2009, http://www.aarpinternational.org/resourcelibra ry/resourcelibrary_show.htm?doc_id=1149378

[47] Thomas Morrow, "Defining the Difference: What makes Biologics Unique," Biotechnology Healthcare, September 2004, pp. 25-29, http://www.biotechnologyhealthcare.com/jo urnal/fulltext/1/4/BH0104024.pdf?CFID=62823907\&CFTO $\mathrm{KEN}=48222339$

[48] “Top 200 Medicines by Sales," MedAdNews, Vol. 29, No. 7, July 2010, pp. 10-15

[49] “Transcript of Oral Argument," Mayo Collaborative Services (dba Mayo Medical Laboratories et al.) v. Prometheus Laboratories, Inc., U.S. Supreme Court, No 10-1150, December 7,2011,http://www.supremecourt.gov/oral_argum ents/argument_transcripts/10-1150.pdf.

[50] "Transfer of Therapeutic Biological Products to the Center for Drug Evaluation and Research," U.S. Food and Drug Administration,

http://www.fda.gov/AboutFDA/CentersOffices/CBER/ucm1 33463.htm 